\title{
Implementation of the Harmonised Model for Carbon Footprint Calculation on Example of the Energy Institute in Croatia
}

\author{
Željko Juric $^{* 1}$, Davor Ljubas ${ }^{2}$, Dinko Đurđevic ${ }^{3}$, Leila Luttenberger ${ }^{4}$ \\ ${ }^{1}$ Department for Renewable Energy Sources, Energy Efficiency and Environmental Protection, \\ Energy Institute Hrvoje Požar, Savska cesta 163, 10001 Zagreb, Croatia \\ e-mail: zjuric@eihp.hr \\ ${ }^{2}$ Faculty of Mechanical Engineering and Naval Architecture, University of Zagreb, Ivana Lučića 5, \\ 10000 Zagreb, Croatia \\ e-mail: davor.ljubas@fsb.hr \\ ${ }^{3}$ Department for Renewable Energy Sources, Energy Efficiency and Environmental Protection, \\ Energy Institute Hrvoje Požar, Savska cesta 163, 10001 Zagreb, Croatia \\ e-mail: ddurdevic@eihp.hr \\ ${ }^{4}$ Department for Renewable Energy Sources, Energy Efficiency and Environmental Protection, \\ Energy Institute Hrvoje Požar, Savska cesta 163, 10001 Zagreb, Croatia \\ e-mail: 1luttenberger@eihp.hr
}

\footnotetext{
Cite as: Jurić, Ž., Ljubas, D., Đurđević, D., Luttenberger, L., Implementation of the Harmonised Model for Carbon Footprint Calculation on Example of the Energy Institute in Croatia, J. sustain. dev. energy water environ. syst., 7(2), pp 368-384, DOI: https://doi.org/10.13044/j.sdewes.d6.0253
}

\begin{abstract}
The effects of climate change on Earth already exist in different forms - as an increase in global average temperatures, as a sea level rise or as extreme weather events, and it is necessary to take significant measures to mitigate and adapt to the climate change. One of the tools that can help in attempts to mitigate climate change is the use of carbon footprint concept, as a measure of the greenhouse gas emissions. Since there are different approaches, it is necessary and possible to establish a harmonised approach for calculating the organisations' carbon footprint, in order to obtain comparable results and benchmarks for different kinds of organisations. The Croatian version of the Bilan Carbone model, fully in accordance with appropriate international standards, with country-specific emission factors database, was tested on the case of the Energy Institute Hrvoje Požar for the period 2015-2017. The carbon footprint for 2017 was 650.6 tonnes or 7.31 tonnes per employee of carbon dioxide equivalent emissions, with dominant shares of people transport (59\%) and energy sources (22\%). This harmonised approach for carbon footprint calculation will lead to comparable results for the same kinds or groups of organisations and therewith, lighten the process of establishing the carbon footprint mitigation strategies.
\end{abstract}

\section{KEYWORDS}

Carbon footprint, Greenhouse gas emission, Emission factor, Climate change, Bilan Carbone ${ }^{\circledR}$ tool, LIFE Clim'Foot project.

\section{INTRODUCTION}

Our planet is faced with constant population growth. During the $20^{\text {th }}$ century, the world population increased from 1.65 billion to 6 billion, reaching 7 billion in 2011 and

\footnotetext{
* Corresponding author
} 
very likely will reach 9 billion by 2050 [1]. Unless the development course is going to change, human requirements will therefore cause increasing pressure on the environment and drastic decrease of its quality [2]. Global environmental threats include the following: $20 \%$ of the Earth's land cover has been degraded by human activities, $60 \%$ of the Earth's ecosystems are damaged or threatened, $40 \%$ of humans are suffering water shortages, and the global average temperatures have risen by about $0.85{ }^{\circ} \mathrm{C}$ since 1880 , and the rise during this century is projected to be up to $4.8^{\circ} \mathrm{C}$ [3].

The effects of climate change already exist in the form of an increase in global average temperatures, a rise of the seas/oceans level and extreme weather events all around the world [4]. According to the World Meteorological Organization (WMO) [5], 2016 was the warmest year since the first measurements, $0.06{ }^{\circ} \mathrm{C}$ above the past record reached in 2015, and 15 of 16 warmest years have occurred in this century. Floods, prolonged drought periods and strong winds with hurricane strength are getting more frequent. Humans influence these changes, among others, through increased Greenhouse gases (GHG's) emissions. Anthropogenic GHG's released to the atmosphere include mostly carbon dioxide $\left(\mathrm{CO}_{2}\right)$, methane $\left(\mathrm{CH}_{4}\right)$, nitrous oxide $\left(\mathrm{N}_{2} \mathrm{O}\right)$, but also other fluorine-containing halogenated gases. $\mathrm{CO}_{2}, \mathrm{CH}_{4}$ and $\mathrm{N}_{2} \mathrm{O}$ emissions can be also formed naturally. However, human activities have a great contribution to their atmospheric concentration increase [6]. The latest analysis of the WMO Global Atmosphere Watch Programme [5] shows that average global concentrations of GHG's reached new records in 2015, with $\mathrm{CO}_{2}$ at $400 \mathrm{ppm}$ (parts per million), $\mathrm{CH}_{4}$ at $1,845 \mathrm{ppb}$ (parts per billion) and $\mathrm{N}_{2} \mathrm{O}$ at $328 \mathrm{ppb}$ or $144 \%, 256 \%$ and $121 \%$ above the pre-industrial levels (before 1750), respectively.

One of the international responses to climate change was prepared in Paris at the $21^{\text {st }}$ Conference of the Parties to the United Nations Framework Convention on Climate Change (UNFCCC) [7], through the global climate agreement. The Paris Agreement commits all countries to take measures to limit emissions and, at the same time, strengthens the role of civil society, organisations, financial institutions, cities, and regions. European Union (EU) has ratified the Paris Agreement and committed to reduce GHG emissions by at least $40 \%$ by 2030, compared to emissions in 1990 [8]. Targeted emission reduction obligation was divided into two parts, the first part comprises the major sources of GHG emissions (industrial facilities, power plants and air transport), namely the participants of the European Emissions Trading Scheme (ETS). Another part of GHG emissions in EU coming from so called non-ETS sectors, which includes the other, relatively small individual emission sources, such as road and off-road transport (except aviation), small power and industrial plants, households, services, agriculture, waste management, forestry, and land use change.

Non-ETS activities are usually included among the diffuse GHG emission sources, which have accounted for approximately $55 \%$ of total GHG emissions in the EU since 2013 [9]. This data suggests that measures designed to reduce diffuse GHG emissions are very important. As part of the solution to reduce GHG emissions in non-ETS sectors of the EU, it is recommended to use a harmonised approach for calculating and reducing the Carbon Footprint $(C F)$ of public and private organisations.

The establishment of a harmonised model for calculation of the $C F$ in non-ETS sectors is the main objective of the LIFE Clim'Foot project (2015-2018) "Climate Governance: Implementing public policies to calculate and reduce organisations' carbon footprint". This three-year project started in September 2015 in five EU countries France, Italy, Greece, Hungary and Croatia. The project coordinator was the French Agency for Environment and Energy Management (ADEME). The goals of the project are to develop and apply five national $C F$ calculation models for organisations, by adapting the comprehensive French Bilan Carbone ${ }^{\circledR}$ tool to national conditions. For the purposes of the models, national databases of emission factors are developed, which 
consist of more than 150 national, country-specific, emission factors for every participating country and at least of $150 \mathrm{EU}$ emission factors. Usage of the Bilan Carbone ${ }^{\circledR}$ model, applicable to different climate and socio-economic regions, will lead to harmonisation of the $C F$ calculation.

In the global attempt to meet the international commitments for the reduction of GHG emissions, organisations integrate the environmental management system in their entire production chains. A review on process integration techniques for carbon emissions and environmental footprint problems is presented in Foo and Tan [10]. Importance of carbon footprinting, as a quantitative expression of GHG emissions, is analysed in Pandey et al. [11]. The carbon footprinting is considered as an essential first step in trying to reduce GHG emissions. The data collected from carbon footprinting can help in identifying, formulating, and implementing activities that can significantly reduce GHG emissions.

In previous research by the author, the integral ecological indicator, which also includes $\mathrm{CO}_{2}$ emissions, was applied on the Croatian thermal power plants, to estimate the environmental impact of each plant [12]. However, the focus in this paper will be on the calculation of anthropogenic GHG emissions, since they are, among others, responsible for global warming and climate changes, one of the biggest problems that humans face nowadays [13].

In 2010, the global anthropogenic GHG emissions were around $50 \mathrm{Gt} \mathrm{CO}_{2 \mathrm{eq}}$ [3]. The major part of this comprises the sum of the personal $C F$ 's of the entire global population. The analyses the $C F$ of inhabitants in India [14], based on surveyed data for 50 rural and urban households showed that the $C F$ of inhabitants in cities is three times higher than the $C F$ of the rural population. Evaluation of personal $C F$ 's can help individuals to understand the magnitude and composition of their footprints, which could lead to their reduction and therefore reduction of the global $C F$ [15].

It is important to point out that GHG emissions from organisations represent a significant part of global anthropogenic emissions. In 2013, direct emissions from the world's 500 largest corporations amounted to $3.6 \mathrm{Gt} \mathrm{CO}_{2 \mathrm{eq}}$, which is about $7 \%$ of global anthropogenic GHG emissions [16]. Consequently, the calculation and reduction of $C F$ by organisations could be part of a solution for GHG emissions reduction and climate change mitigation.

Major changes to reduce GHG emissions are already happening in the energy sector, which is responsible for about $2 / 3$ of anthropogenic GHG emissions, as analysed in a book devoted to the energy transition of Europe [17]. The book was created in order to bridge the gap between scientific research and energy-climate policy for the purpose of low-emission development in Europe. Reducing energy consumption and $C F$, with the aim of low-emission development, was also considered in Chakraborty and Roy [18].

It is useful to compare the $C F$ of some countries or regions, which is explained in Hertwich and Peters [19]. The $C F$ is determined for 73 countries and 14 world regions based on final energy, goods and services consumption. Mapping of the $C F$, using a model based on final consumption, with special focus to the USA, Germany, China and Japan, is presented in Kanemoto et al. [20]. Assessment of $C F$ in different industrial sectors is given in Muthu and Golinska [21], while methodological and modelling aspects of $C F$, as well as case studies of $C F$ calculation is presented in Muthu and Abanda [22].

In order to determine $C F$, it is important to set boundaries well and identify the activities that need to be included in the calculation, which is the subject of analysis within the Lombardi et al. [23]. Currently, there are several available standards for $C F$ calculation of organisations and products. Comparative analysis of $C F$ standards was presented in Gao et al. [24]. The ISO standard [25] and GHG protocol [26] for $C F$ calculation of organisations and four selected standards for $C F$ calculation of products were analysed. The analysis of the possibilities for establishment of a universal approach for calculating the $C F$ of organisations, with emphasis on universities, was given in 
Robinson et al. [16], while the quantitative analysis of factors affecting GHG emissions at higher education institutions was carried out in Klein-Banai and Theis [27]. On the other hand, a comparison of the methodology for $C F$ calculation of products, on the example of office paper, was presented in Dias and Arroja [28]. The method for real-time aggregation of a product $C F$ during manufacturing was shown in Smolek et al. [29], while the analysis of the methods used for the calculation of $C F$ for over 1,500 products was given in the paper Barnett et al. [30].

There are many studies dedicated to the $C F$ calculation and reduction. Most of them consider corrective measures, but rarely preventive measures [6]. Moreover, most of the research analyses the $C F$ calculations use an input-output balance model [31] or a consumption-based approach for existing facilities or infrastructure, which focuses on corrective rather than preventive measures. On the other hand, preventive measures for existing facilities are usually easier and cheaper to implement than the corrective ones.

The $C F$ calculation for the Faculty of environment and resource studies in Thailand was presented in Aroonsrimorakot et al. [32], while the $C F$ calculation on the level of students was described in Utaraskul [33]. The realisation of a low carbon emission of a university campus was analysed in Abdul-Azeez and Ho [34], while the influence of energy management plans and carbon emission reduction on an institution's green reputation was explored in Komarek et al. [35]. However, the problem is the usage of numerous models and approaches for $C F$ calculation, with different range of input data and emission factors, and thus the results cannot be comparable. So, this paper highlights the necessity of establishing a harmonised approach for calculating the $C F$ of organisations, to obtain comparable results and benchmarks for different kinds of organisations. This harmonised model for calculating the $C F$ of organisations should be fully in accordance with appropriate ISO 14064 norm and GHG protocol.

\section{METHOD}

The $C F$ is a significant component of environmental footprint and could be defined as the total amount of GHG, directly and indirectly emitted in the atmosphere by a project, a person, an event, an organisation, or a product. GHG's can be emitted through different human activities, such as the transport of people and goods, production and consumption of food, fuels, materials and services [36].

The $C F$ of the organisation includes calculation of emissions by sources and removals by sinks of all anthropogenic GHG's $\left(\mathrm{CO}_{2}, \mathrm{CH}_{4}, \mathrm{~N}_{2} \mathrm{O}\right.$, PFC's, HFC's, $\mathrm{SF}_{6}$ and $\left.\mathrm{NF}_{3}\right)$ at the level of organisation, applying the Life Cycle Assessment (LCA) approach. Total emissions are expressed as equivalent $\mathrm{CO}_{2}$ emissions $\left(\mathrm{CO}_{2 \mathrm{eq}}\right)$, using the Global Warming Potential (GWP) of each GHG.

\section{International standards for carbon footprint calculation}

There are different methods for calculating the $C F$ of organisations. Two of them are internationally accepted: GHG protocol and ISO standards (14064-1 \& ISO/TR 14069).

GHG Protocol Corporate Accounting and Reporting Standard [26] provides methods and guidelines for the calculation of the $C F$ for direct GHG emissions (Scope 1), such as the combustion of fossil fuels, production processes and internal transportation, and indirect emissions (Scope 2) from consumption of electricity and heat/cool energy, produced outside of the organisation's location. Appendix of the Protocol, with detailed guidelines for the calculation of indirect energy related emissions, is given in the Scope 2 Guidance [37]. Methodological instructions for calculating the $C F$ of organisations are completed with detailed guidelines for the calculation of GHG emissions of all input and output flows required for the functioning of the organisation (Scope 3) - GHG Protocol Corporate Value Chain (Scope 3) Standard [38] and technical guidelines for calculation 
of indirect Scope 3 emissions - Technical Guidance for Calculating Scope 3 Emissions [39].

Alongside the GHG protocol, calculating the $C F$ is also defined by the ISO standards. The framework for the calculation of the environmental footprint is given in ISO 14040 [40] and ISO 14044 [41] standards, while the guidelines for the calculation of the $C F$ are given in the ISO 14064 standard from 2006. The standard has three components, the first one [25] is intended for the calculation and reporting of emissions/removal of GHG emissions on the level of the organisation, the second component [42] is on the project level and provides guidance for calculating, monitoring and reporting of GHG emissions reduction or increase, while the third component [43] is designed for the validation and verification of calculation. In addition to the above-mentioned standards, ISO/TR 14069 [44] norm is prepared, which provides guidance for the application of ISO 14064-1 [25] on the level of organisation.

In the calculation of the $C F$ of organisations, it is necessary to use the LCA approach, which involves the calculation of all direct and indirect GHG emissions from all on-site or off-site activities that are related to the organisation business, regardless of the level of impact. In addition to the activities for which the organisation is responsible, it is necessary to include all other activities of input and output flows on which the organisation is dependent. Only if the activity does not have a significant impact on the observed company, it can be considered unnecessary in the calculation of the $C F$.

International standard ISO 14064 and GHG Protocol define three scopes for GHG emission calculation, as shown in eq. (1):

$$
C F_{\mathrm{O}}=D E_{\mathrm{S} 1}+I E_{\mathrm{S} 2}+I E_{\mathrm{S} 3}
$$

where $C F_{\mathrm{O}}$ is $C F$ of the organisation [ $\mathrm{t} \mathrm{CO}_{2 \mathrm{eq}}$ ], $D E_{\mathrm{S} 1}$ is direct $\mathrm{GHG}$ emissions [ $\mathrm{t}_{2 \mathrm{eq}}$ ]occur on-site, whether due to fuel combustion, the production process and/or the company's vehicles (Scope 1), $I E_{\mathrm{S} 2}$ is indirect $\mathrm{GHG}$ emissions [ $\mathrm{CO}_{2 \mathrm{eq}}$ - occur off-site, associated with the acquisition and consumption of electricity, heating and cooling (Scope 2), $I E_{\mathrm{S} 3}$ is indirect $\mathrm{GHG}$ emissions [ $\mathrm{t} \mathrm{CO}_{2 \mathrm{eq}}$ - occur off-site, include all activities connected to the input and output flows of materials and people necessary for the functioning of the organisation's system (Scope 3).

\section{Model for carbon footprint calculation}

Considering the methodological guidelines, defined by the GHG Protocol and ISO standards, the Bilan Carbone ${ }^{\circledR}$ model for the calculation of the $C F$ of organisations was developed by ADEME (Figure 1).

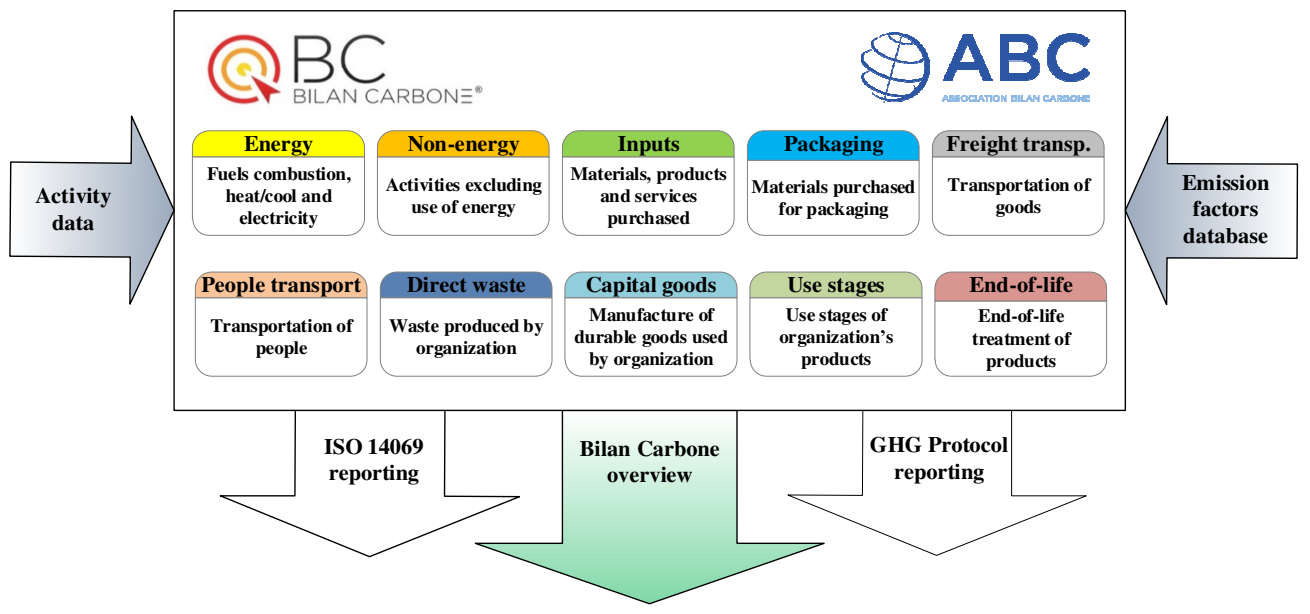

Figure 1. The Bilan Carbone ${ }^{\circledR}$ model for $C F$ calculation of organisations 
In the development of the Croatian model and country-specific emission factors, several other documents were used, among them are guidelines and reports of the IPCC methodological guidance of the IPCC for the preparation of national GHG inventories [45] and the Fifth report of the IPCC [3].

The Bilan Carbone ${ }^{\circledR}$ model, version V7.4, offers the possibility to calculate the emissions of GHG's from all activities relevant to the organisations' operations, divided in the ten source categories [eq. (2)]:

$$
C F_{\mathrm{O}}=E_{\mathrm{ES}}+E_{\mathrm{NS}}+E_{\mathrm{IN}}+E_{\mathrm{PC}}+E_{\mathrm{TP}}+E_{\mathrm{TG}}+E_{\mathrm{DW}}+E_{\mathrm{US}}+E_{\mathrm{EL}}+E_{\mathrm{CG}}
$$

where $C F_{\mathrm{O}}$ is $C F$ of the organisation [ $\mathrm{t} \mathrm{CO}_{2 \mathrm{eq}}$ ], $E_{\mathrm{ES}}$ is the energy sources [ $\mathrm{t} \mathrm{CO}_{2 \mathrm{eq}}$ - mainly $\mathrm{CO}_{2}$ emissions from on-site combustion of fuel and from purchase of electricity, heating and cooling, $E_{\mathrm{NS}}$ is the non-energy sources $\left[\mathrm{t} \mathrm{CO}_{2 \mathrm{eq}}\right]-\mathrm{CO}_{2}$ emissions from industrial processes, $\mathrm{N}_{2} \mathrm{O}$ emissions from manure management and animal enteric fermentation, $\mathrm{CH}_{4}$ emissions from animal fermentation and fugitive emissions from fossil and organic fuels, $E_{\mathrm{IN}}$ is input of materials and services [ $\mathrm{t} \mathrm{CO}_{2 \mathrm{eq}}$ - production of metal, plastic, glass, paper and cardboard, building materials, chemical products, agricultural products, other inputs and different services, $E_{\mathrm{PC}}$ is packaging $\left[\mathrm{t} \mathrm{CO}_{2 \mathrm{eq}}\right]$ - production of materials for packaging with similar structure to the previous input materials and services, $E_{\mathrm{TP}}$ is transport of persons [ $\mathrm{t} \mathrm{CO}_{2 \mathrm{eq}}$ - transport of people (commuting - to work and back, employee's business travels and visitors' travels), using different vehicles (cars, buses, trains, motorcycles, boats and planes), $E_{\mathrm{TG}}$ is transport of goods $\left[\mathrm{t} \mathrm{CO}_{2 \mathrm{eq}}\right]$ - upstream and downstream flows and internal freight transport (road, air, rail and water transport), $E_{\mathrm{DW}}$ is direct waste $\left[\mathrm{t} \mathrm{CO}_{2 \mathrm{eq}}\right]$ - non-hazardous and hazardous waste management and wastewater treatment, $E_{\mathrm{US}}$ is the use stages [ $\mathrm{t}^{\mathrm{CO}_{2 \mathrm{eq}}}$ - emissions from fuel, electricity or heat/cool energy consumption during the use of the product, but also the emissions not related to energy consumption, $E_{\mathrm{EL}}$ is end-of-life $\left[\mathrm{t} \mathrm{CO}_{2 \mathrm{eq}}\right]$ - emissions related to the end-of-life cycle, and may include the energy consumption (e.g. at the end of the life cycle of a building, it is necessary to use energy for its decommission), but it is mainly materials that have come to their end of life (hazardous or non-hazardous waste or leakages of refrigerants), $E_{\mathrm{CG}}$ is the capital goods [ $\mathrm{t} \mathrm{CO}_{2 \mathrm{eq}}$ - emissions related to real estate, movable property and equipment used for longer periods of time such as buildings, furniture, IT equipment or vehicles, where the emissions associated with their production should be calculated and distributed through the depreciation period.

The GHG emission of a source category is a sum of GHG emissions for every single emission source recognised within the category [eq. (3)]:

$$
E_{\mathrm{SC}}=\sum_{i=1}^{n} E_{\mathrm{ES}, i}
$$

where $E_{\mathrm{SC}}$ is $\mathrm{GHG}$ emission of a source category [ $\mathrm{t} \mathrm{CO}_{2 \mathrm{eq}}$ ], $E_{\mathrm{ES}, i}$ is $\mathrm{GHG}$ emission of a source $i\left[\mathrm{t} \mathrm{CO}_{2 \mathrm{eq}}\right]$.

The GHG emission of a source is the product of activity data and emission factor [eq. (4)]:

$$
E_{\mathrm{ES}, i}=A D_{i} \times E F_{i}
$$

where $E_{\mathrm{ES}, i}$ is $\mathrm{GHG}$ emission of a source $i$ [t $\left.\mathrm{CO}_{2 \mathrm{eq}}\right], A D_{i}$ is activity data of a source $i$ [unit], $E F_{i}$ is the emission factor of a source $i\left[\mathrm{t} \mathrm{CO}_{2 \mathrm{eq}} / \mathrm{unit}\right]$.

The Bilan Carbone ${ }^{\circledR}$ model also gives an overview of the calculated $C F$, according to the GHG Protocol and ISO/TR 14069 standard, and the emissions are distributed in appropriate scopes $-1,2$ and 3 . 


\section{RESULTS AND DISCUSSION}

The Bilan Carbone ${ }^{\circledR}$ model has been designed to estimate GHG emissions by converting specific information collected on the processes and flows of the organisation's activities into estimated GHG emissions using emission factors. The model was used to assess the $C F$ of Energy Institute Hrvoje Požar (EIHP), as one of ten pilot organisations in Croatia in the framework of LIFE Clim'Foot project.

\section{Results of the carbon footprint calculation for the Institute}

The $C F$ of EIHP was calculated for the years 2015, 2016 and 2017. There was an increase in the number of employees for the analysed period. At the beginning of 2015 , the number of employees in EIHP was 75, while at the end of 2017 it was 89. Average numbers of employees for 2015 (79), 2016 (86) and 2017 (89) were used in the following calculation.

Using Bilan Carbone ${ }^{\circledR}$ model, the carbon footprint calculation takes into consideration all flows of energy, materials and people under the responsibility and dependency of the EIHP. Figure 2 gives an overview of activities on location, as well as the upstream and downstream flows, with the corresponding scopes.

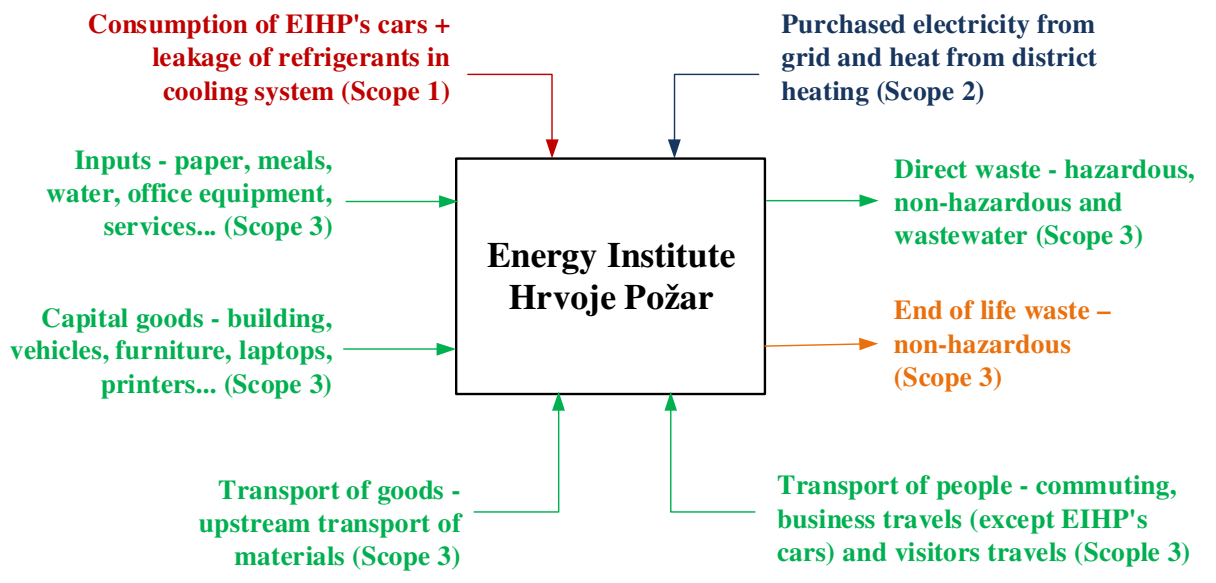

Legend:

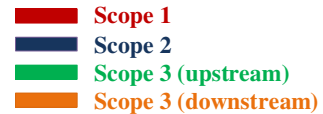

Figure 2. Overview of activities considered in the EIHP's $C F$ calculation

The results of the $C F$ calculation for the period from 2015 to 2017 are presented in Table 1. The Table indicates that the following four main emission sources represent around $98 \%$ of EIHP's $C F$ : Transport of people, Energy sources, Capital goods and Input of materials and services.

Table 1. The EIHP's $C F$ by emission categories for 2015, 2016 and 2017

\begin{tabular}{|c|c|c|c|c|c|c|}
\hline \multirow{2}{*}{ Emission categories } & \multicolumn{2}{|c|}{2015} & \multicolumn{2}{|c|}{2016} & \multicolumn{2}{|c|}{2017} \\
\hline & {$\left[\mathrm{t} \mathrm{CO}_{2 \mathrm{eq}}\right]$} & {$[\%]$} & {$\left[\mathrm{t} \mathrm{CO}_{2 \mathrm{eq}}\right]$} & [\%] & {$\left[\mathrm{t} \mathrm{CO}_{2 \mathrm{eq}}\right]$} & {$[\%]$} \\
\hline Energy sources & 153.2 & 26.0 & 154.4 & 24.7 & 145.0 & 22.3 \\
\hline Non-energy sources & 7.2 & 1.2 & 7.2 & 1.2 & 7.2 & 1.1 \\
\hline Inputs & 46.8 & 8.0 & 48.8 & 7.8 & 45.1 & 6.9 \\
\hline Transport of people & 313.7 & 53.3 & 345.5 & 55.2 & 386.8 & 59.5 \\
\hline Transport of goods & 3.5 & 0.59 & 3.9 & 0.63 & 4.0 & 0.61 \\
\hline Direct waste & 1.2 & 0.21 & 1.2 & 0.19 & 1.1 & 0.17 \\
\hline End of life & 0.054 & 0.009 & 0.061 & 0.010 & 0.062 & 0.010 \\
\hline Capital goods & 63.0 & 10.7 & 64.8 & 10.3 & 61.3 & 9.4 \\
\hline EIHP's $C F$ & 588.7 & 100.0 & 625.9 & 100.0 & 650.6 & 100.0 \\
\hline
\end{tabular}


More details on the $C F$ of EIHP are presented in Tables 2 and 3, with specific information on data used and emission factors by each group of emission sources.

Table 2. The $C F$ calculation for EIHP: Energy sources, Input of materials and services and Transport of people

\begin{tabular}{|c|c|c|c|c|c|c|c|c|c|c|}
\hline \multirow[t]{2}{*}{$\begin{array}{l}\text { Emission } \\
\text { category }\end{array}$} & \multirow[t]{2}{*}{ Emission source } & \multicolumn{3}{|c|}{ Data value } & \multirow[t]{2}{*}{ Data unit } & \multirow[t]{2}{*}{$\begin{array}{c}\text { Emission } \\
\text { factor }\end{array}$} & \multirow[t]{2}{*}{$\begin{array}{c}\text { Emission } \\
\text { factor unit }\end{array}$} & \multicolumn{3}{|c|}{ Emissions [kg CO $\left.\mathrm{kO}_{2 \mathrm{eq}}\right]$} \\
\hline & & 2015 & 2016 & 2017 & & & & 2015 & 2016 & 2017 \\
\hline \multirow{3}{*}{ Energy sources } & Purchased electricity from grid & 251,596 & 234,293 & 229,524 & {$[\mathrm{kWh}]$} & 0.351 & {$\left[\mathrm{~kg} \mathrm{CO}_{2 \mathrm{eq}} / \mathrm{kWh}\right]$} & 88,361 & 82,284 & 80,609 \\
\hline & Purchased heat from district heating & 161,702 & 183,994 & 163,182 & {$[\mathrm{kWh}]$} & 0.350 & {$\left[\mathrm{~kg} \mathrm{CO}_{2 \mathrm{eq}} / \mathrm{kWh}\right]$} & 56,596 & 64,398 & 57,114 \\
\hline & Electricity grid losses & 251,596 & 234,293 & 229,524 & {$[\mathrm{kWh}]$} & 0.032 & {$\left[\mathrm{~kg} \mathrm{CO}_{2 \mathrm{eq}} / \mathrm{kWh}\right]$} & 8,247 & 7,680 & 7,277 \\
\hline \multirow{9}{*}{$\begin{array}{l}\text { Input of materials } \\
\text { and services }\end{array}$} & Paper for printing and other purposes & 950 & 1,078 & 1,098 & {$[\mathrm{~kg}]$} & 0.718 & {$[\mathrm{~kg} \mathrm{CO} 2 \mathrm{cq} / \mathrm{kg}]$} & 682 & 774 & 788 \\
\hline & Meals - typical meal with chicken & 5,569 & 6,020 & 6,246 & [meal] & 1.100 & {$\left[\mathrm{~kg} \mathrm{CO}_{2 \mathrm{eq}} /\right.$ meal $]$} & 6,125 & 6,622 & 6,870 \\
\hline & Meals - typical meal with pork & 3,341 & 3,612 & 3,747 & [meal] & 1.930 & {$\left[\mathrm{~kg} \mathrm{CO}_{2 \mathrm{eq}} /\right.$ meal $]$} & 6,448 & 6,971 & 7,233 \\
\hline & Meals - typical meal with beef & 2,227 & 2,408 & 2,498 & [meal] & 4.510 & {$\left[\mathrm{~kg} \mathrm{CO}_{2 \mathrm{eq}} /\right.$ meal $]$} & 10,046 & 10,860 & 11,267 \\
\hline & Meals $-2 / 3$ fish and $1 / 3$ vegetarian meal & 4,773 & 5,160 & 5,354 & [meal] & 0.460 & {$\left[\mathrm{~kg} \mathrm{CO}_{2 \mathrm{eq}} /\right.$ meal $]$} & 2,196 & 2,374 & 2,463 \\
\hline & Water consumption & 1,314 & 1,118 & 1,001 & {$\left[\mathrm{~m}^{3}\right]$} & 0.132 & {$\left[\mathrm{~kg} \mathrm{CO}_{2 \mathrm{eq}} / \mathrm{m}^{3}\right]$} & 173 & 148 & 132 \\
\hline & Office equipment & 12,623 & 11,944 & 7,411 & [EUR] & 0.917 & {$\left[\mathrm{~kg} \mathrm{CO}_{2 \mathrm{eq}} / \mathrm{EUR}\right]$} & 11,575 & 10,952 & 6,796 \\
\hline & Services with low level of equipment & 189,370 & 186,677 & 182,336 & [EUR] & 0.037 & {$\left[\mathrm{~kg} \mathrm{CO}_{2 \mathrm{eq}} / \mathrm{EUR}\right]$} & 6,950 & 6,851 & 6,692 \\
\hline & Services with high level of equipment & 24,083 & 29,751 & 25,870 & [EUR] & 0.110 & {$\left[\mathrm{~kg} \mathrm{CO}_{2 \mathrm{eq}} / \mathrm{EUR}\right]$} & 2,649 & 3,273 & 2,846 \\
\hline \multirow{14}{*}{$\begin{array}{c}\text { Transport of } \\
\text { people }\end{array}$} & Employees commuting by diesel cars & 12,849 & 13,995 & 14,486 & {$[\mathrm{~L}]$} & 3.230 & {$\left[\mathrm{~kg} \mathrm{CO}_{2 \mathrm{eq}} / \mathrm{L}\right]$} & 41,497 & 45,197 & 46,783 \\
\hline & Employees commuting by gasoline cars & 6,162 & 6,711 & 6,947 & {$[\mathrm{~L}]$} & 2.805 & {$\left[\mathrm{~kg} \mathrm{CO}_{2 \mathrm{cq}} / \mathrm{L}\right]$} & 17,281 & 18,822 & 19,482 \\
\hline & Employees commuting by tram & 20,984 & 22,855 & 23,657 & {$[\mathrm{p} \mathrm{km}]$} & 0.007 & {$\left[\mathrm{~kg} \mathrm{CO}_{2 \mathrm{eq}} / \mathrm{p} \mathrm{km}\right]$} & 139 & 152 & 157 \\
\hline & Employees commuting by bus & 5,031 & 5,480 & 5,672 & {$[\mathrm{p} \mathrm{km}]$} & 0.154 & {$\left[\mathrm{~kg} \mathrm{CO}_{2 \mathrm{eq}} / \mathrm{p} \mathrm{km}\right]$} & 776 & 845 & 874 \\
\hline & Business travels by EIHP's diesel cars & 7,299 & 10,381 & 10,674 & {$[\mathrm{~L}]$} & 3.230 & {$\left[\mathrm{~kg} \mathrm{CO}_{2 \mathrm{eq}} / \mathrm{L}\right]$} & 23,571 & 33,526 & 34,474 \\
\hline & Business travels by private diesel cars & 164 & 106 & 335 & [L] & 3.230 & {$\left[\mathrm{~kg} \mathrm{CO}_{2 \mathrm{eq}} / \mathrm{L}\right]$} & 529 & 342 & 1,080 \\
\hline & Business travels by private gasoline cars & 76 & 49 & 156 & {$[\mathrm{~L}]$} & 2.805 & {$\left[\mathrm{~kg} \mathrm{CO}_{2 \mathrm{eq}} / \mathrm{L}\right]$} & 214 & 139 & 438 \\
\hline & Business travels by bus & 3,714 & 8,804 & 7,110 & {$[\mathrm{p} \mathrm{km}]$} & 0.154 & {$\left[\mathrm{~kg} \mathrm{CO}_{2 \mathrm{eq}} / \mathrm{p} \mathrm{km}\right]$} & 573 & 1,357 & 1,096 \\
\hline & Business travels by train & 600 & 1,600 & 0 & {$[\mathrm{p} \mathrm{km}]$} & 0.023 & {$\left[\mathrm{~kg} \mathrm{CO}_{2 \mathrm{eq}} / \mathrm{p} \mathrm{km}\right]$} & 14 & 37 & 0 \\
\hline & Business travels by plane & 490,008 & 537,540 & 660,954 & {$[\mathrm{p} \mathrm{km}]$} & 0.319 & {$\left[\mathrm{~kg} \mathrm{CO}_{2 \mathrm{eq}} / \mathrm{p} \mathrm{km}\right]$} & 156,176 & 171,325 & 210,448 \\
\hline & Visitors travels by diesel cars & 3,085 & 3,123 & 3,160 & {$[\mathrm{~L}]$} & 3.230 & {$\left[\mathrm{~kg} \mathrm{CO}_{2 \mathrm{ce}} / \mathrm{L}\right]$} & 9,965 & 10,087 & 10,204 \\
\hline & Visitors travels by gasoline cars & 2,289 & 2,317 & 2,347 & {$[\mathrm{~L}]$} & 2.805 & {$\left[\mathrm{~kg} \mathrm{CO}_{2 \mathrm{eq}} / \mathrm{L}\right]$} & 6,419 & 6,497 & 6,583 \\
\hline & Visitors travels by tram & 3,681 & 3,726 & 3,852 & {$[\mathrm{p} \mathrm{km}]$} & 0.007 & {$\left[\mathrm{~kg} \mathrm{CO}_{2 \mathrm{eq}} / \mathrm{p} \mathrm{km}\right]$} & 24 & 25 & 26 \\
\hline & Visitors travels by plane & 178,679 & 180,867 & 173,340 & {$[\mathrm{p} \mathrm{km}]$} & 0.319 & {$\left[\mathrm{~kg} \mathrm{CO}_{2 \mathrm{cq}} / \mathrm{p} \mathrm{km}\right]$} & 56,949 & 57,646 & 55,191 \\
\hline
\end{tabular}

Table 3. The $C F$ calculation for EIHP: Transport of goods, Non-energy sources, Direct waste, End of life and Capital goods

\begin{tabular}{|c|c|c|c|c|c|c|c|c|c|c|}
\hline \multirow[t]{2}{*}{ Emission category } & \multirow[t]{2}{*}{ Emission source } & \multicolumn{3}{|c|}{ Data value } & \multirow[t]{2}{*}{ Data unit } & \multirow{2}{*}{$\begin{array}{c}\text { Emission } \\
\text { factor }\end{array}$} & \multirow{2}{*}{$\begin{array}{c}\text { Emission } \\
\text { factor unit }\end{array}$} & \multicolumn{3}{|c|}{ Emissions $\left[\mathrm{kg} \mathrm{CO}_{2<\mathrm{q}}\right]$} \\
\hline & & 2015 & 2016 & 2017 & & & & 2015 & 2016 & 2017 \\
\hline \multirow{2}{*}{ Transport of goods } & Upstream transport of paper & 2,613 & 2,963 & 3,018 & {$[\mathrm{t} \mathrm{km]}$} & 1.233 & {$\left[\mathrm{~kg} \mathrm{CO}_{2 \mathrm{eq}} / \mathrm{t} \mathrm{km}\right]$} & 3,223 & 3,654 & 3,722 \\
\hline & Downstream transport of studies & 75 & 81 & & {$[\mathrm{~L}]$} & 3.230 & {$\left[\mathrm{~kg} \mathrm{CO}_{2 \mathrm{ce}} / \mathrm{L}\right]$} & 241 & 262 & 272 \\
\hline Non-energy sources & Leakage of refrigerant (R417a) in the cooling system & 2,910 & 2,910 & 2,910 & {$[\mathrm{~g}]$} & 2.490 & {$\left[\mathrm{~kg} \mathrm{CO}_{2 \mathrm{eq}} / \mathrm{g}\right]$} & 7,246 & 7,246 & 7,246 \\
\hline \multirow{5}{*}{ Direct waste } & Non-hazardous waste - recycled paper & 713 & 808 & 823 & {$[\mathrm{~kg}]$} & 0.033 & {$\left[\mathrm{~kg} \mathrm{CO}_{2 \mathrm{eq}} / \mathrm{kg}\right]$} & 23.5 & 26.7 & 27.2 \\
\hline & Non-hazardous waste - recycled plastic & 269 & 284 & 290 & {$[\mathrm{~kg}]$} & 0.033 & {$\left[\mathrm{~kg} \mathrm{CO}_{2 \mathrm{eq}} / \mathrm{kg}\right]$} & 8.9 & 9.4 & 9.6 \\
\hline & Non-hazardous waste - organic/food & 1,305 & 1,295 & 1,387 & {$[\mathrm{~kg}]$} & 0.558 & {$\left[\mathrm{~kg} \mathrm{CO}_{2 \mathrm{eq}} / \mathrm{kg}\right]$} & 728 & 723 & 774 \\
\hline & Hazardous waste (e.g. electronic waste) & 836 & 831 & 448 & {$[\mathrm{~kg}]$} & 0.128 & {$\left[\mathrm{~kg} \mathrm{CO}_{2 \mathrm{eq}} / \mathrm{kg}\right]$} & 107 & 106 & 57 \\
\hline & Wastewater & 1,314 & 1,118 & 1,001 & {$\left[\mathrm{~m}^{3}\right]$} & 0.262 & {$\left[\mathrm{~kg} \mathrm{CO}_{2 \mathrm{cq}} / \mathrm{m}^{3}\right]$} & 344 & 293 & 262 \\
\hline \multirow{2}{*}{ End of life } & Non-hazardous waste - recycled paper & 238 & 269 & 274 & {$[\mathrm{~kg}]$} & 0.235 & {$\left[\mathrm{~kg} \mathrm{CO}_{2 \mathrm{eq}} / \mathrm{kg}\right]$} & 53 & 60 & 61 \\
\hline & Non-hazardous waste - recycled plastic & 36 & 40 & 41 & {$[\mathrm{~kg}]$} & 0.880 & {$\left[\mathrm{~kg} \mathrm{CO}_{2 \mathrm{eq}} / \mathrm{kg}\right]$} & 1.2 & 1.3 & 1.4 \\
\hline \multirow{7}{*}{ Capital goods } & EIHP's building (depr. period: 40 years) & 2,144 & 2,144 & 2,144 & {$\left[\mathrm{~m}^{2}\right]$} & 11.725 & {$\left[\mathrm{~kg} \mathrm{CO}_{2 \mathrm{cq}} / \mathrm{m}^{2}\right]$} & 25,138 & 25,138 & 25,138 \\
\hline & Vehicles (depreciation period: 4 years) & 5,536 & 5,378 & 5,132 & {$[\mathrm{~kg}]$} & 1.375 & {$\left[\mathrm{~kg} \mathrm{CO}_{2 \mathrm{eq}} / \mathrm{kg}\right]$} & 7,612 & 7,394 & 7,057 \\
\hline & Furniture (depreciation period: 5 years) & 910 & 2,095 & 2,095 & {$[\mathrm{~kg}]$} & 0.367 & {$\left[\mathrm{~kg} \mathrm{CO}_{2 \mathrm{eq}} / \mathrm{kg}\right]$} & 334 & 768 & 768 \\
\hline & IT equipment (depr. period: 4 years) & 16,148 & 16,148 & 16,148 & [EUR] & 0.229 & {$[\mathrm{~kg} \mathrm{CO} 2 \mathrm{eq} / \mathrm{EUR}]$} & 3,702 & 3,702 & 3,702 \\
\hline & Laptops and PC's (depr. period: 4 years) & 67 & 64 & 62 & [unit] & 0.320 & {$\left[\mathrm{t} \mathrm{CO}_{2 \mathrm{eq}} /\right.$ unit $]$} & 21,440 & 20,480 & 19,840 \\
\hline & Monitors (depreciation period: 4 years) & 13 & 28 & 15 & [unit] & 0.192 & {$\left[\mathrm{t} \mathrm{CO}_{2 \mathrm{eq}} /\right.$ unit $]$} & 2,493 & 5,369 & 2,876 \\
\hline & Printers and copy (depr. period: 4 years) & 6 & 5 & 5 & [unit] & 0.381 & [t CO $2 e q /$ unit $]$ & 2,288 & 1,906 & 1,906 \\
\hline
\end{tabular}

\section{Discussion of the results of Institute's carbon footprint calculation}

Energy sources are related to the electricity and heat consumption of EIHP. Country-specific emission factor for average electricity consumption in Croatia, based on the electricity mix supply system for the period from 2010 to 2015, was used in the calculation. National emission factor for heat consumption was also used, calculated for average district heating supply from public combined heat and power plants in Zagreb in the same period. Non-energy consumption refers to the leakage of refrigerant (R417a) from the cooling system at the EIHP's building. The circuit that contains the refrigerant is never completely leak-proof and during operation $10 \%$ of leakage per year was estimated in the calculation. The GHG emissions from energy and non-energy sources are shown in Figure 3.

GHG emissions from input of materials and services (Figure 4) encompasses all incoming flows of materials and services used by EIHP, or more precisely supplies of paper, water, food, office equipment, and services provided by external providers (catering, cleaning, consultancy, external translation and interpreting, insurances, etc.). 
The emission category connected to packaging is not appropriate for EIHP. It could only consist of envelopes and cardboard boxes, but it was estimated in this category, together with other paper. Emission factors from the Bilan Carbone ${ }^{\circledR}$ model were used for calculation.

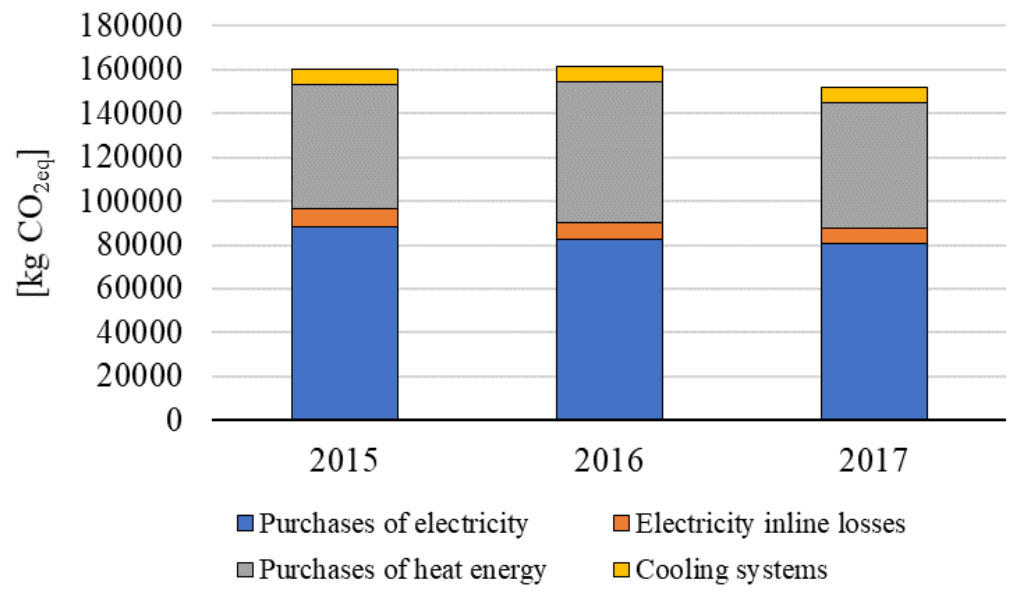

Figure 3. GHG emissions from energy and non-energy sources

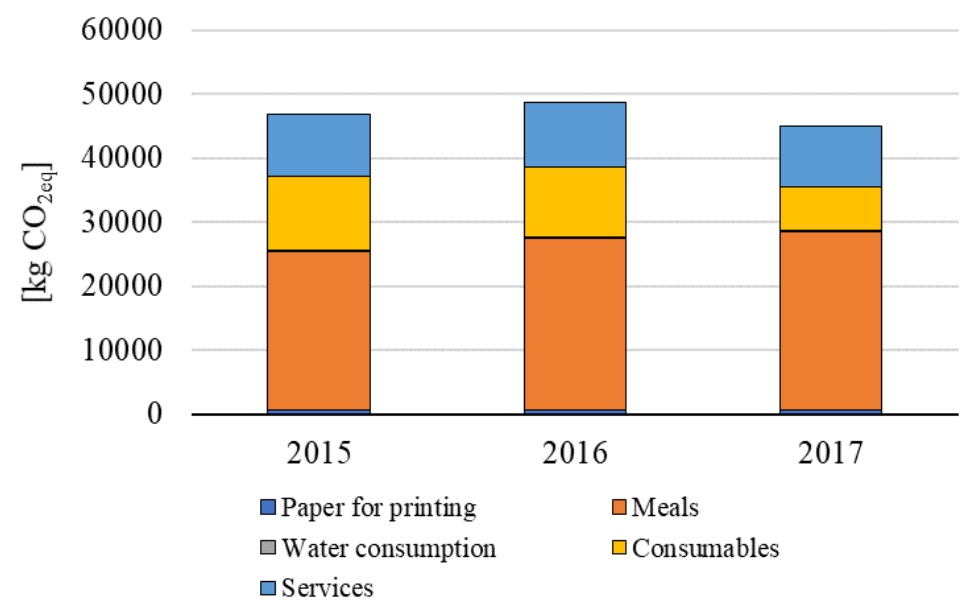

Figure 4. GHG emissions from input of materials and services

Transport of people includes commuting of EIHP's employees, business travels and visitors' travels. Commuting of employees was investigated using the survey with questions on transport means (34\% of employees travel by bicycle or on foot), the distance between home and office, and in the case of using cars - car occupancy (car sharing), type of cars (e.g. diesel or gasoline) and fuel consumption. A detailed bottom-up approach was used for the calculation of business travels, using appropriate data for every single travel in 2015, 2016 and 2017. The number of visitors was determined on the basis of registered guests at the entry port, while the structure of transport means and distance for travels of visitors were estimated, based on the special questionnaire. National emission factors for diesel fuel and gasoline consumption, as well as for the travels by train and plane, determined in the framework of the LIFE Clim'Foot project, were applied. Transport of goods covers the upstream transport of paper between the provider's location in Portugal and the EIHP's building, as well as the downstream transport of final products (studies) by official diesel cars. The combination of country-specific and default emission factors from the Bilan Carbone ${ }^{\circledR}$ model was used in the calculation. Figure 5 presents the GHG emissions from people and freight transport. 


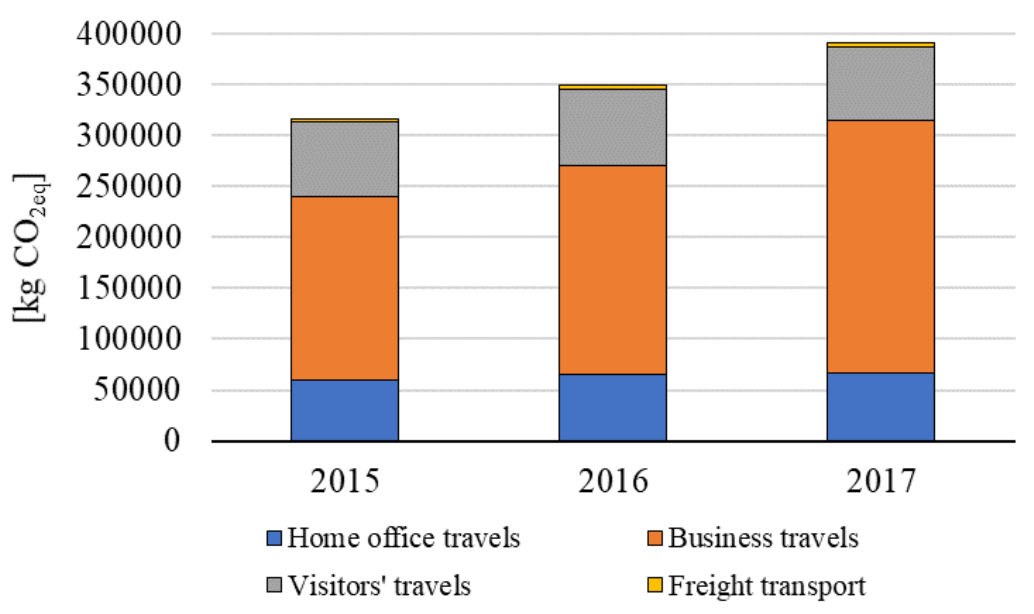

Figure 5. GHG emissions from people and freight transport

The waste was also included in the GHG emission calculation. Identified non-hazardous waste was paper, plastic and organic waste, while hazardous waste was electronic equipment, toners, batteries, light bulbs and tubes. Additionally, direct waste also covers wastewater treatment. Paper and plastic were recycled, while other waste was given to the licensed waste management companies. Similar to the GHG emission calculation for direct waste, the $C F$ of the end-of-life waste processing was estimated. The main outputs of EIHP were various studies in the area of sustainable energy development, environmental protection, climate change mitigation and adaptation. There are no emissions during studies' usage stages, while emissions of the end-of-life were calculated as non-hazardous waste. Emission factors from the Bilan Carbone ${ }^{\circledR}$ model were used for the calculation of GHG emissions from end-of-life and direct waste categories (Figure 6).

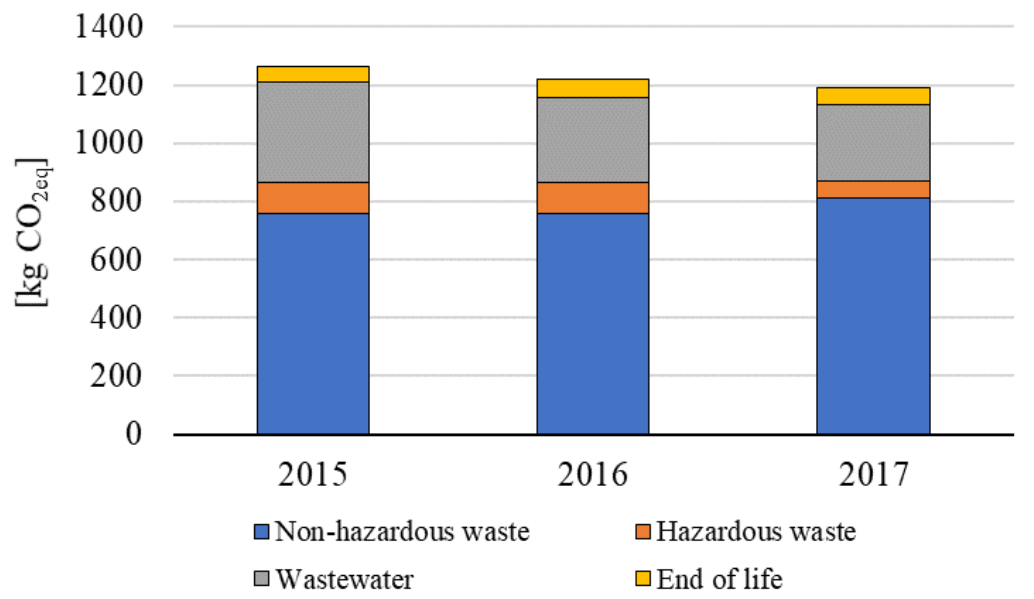

Figure 6. GHG emissions from direct waste and end-of-life

Capital goods include GHG emissions generated during the manufacture or construction of EIHP's fixed assets, using default emission factors (Figure 7). Under the Bilan Carbone ${ }^{\circledR}$ model, GHG emissions are divided by the number of years of the depreciation period, which is in accordance with the financial concept of amortisation. EIHP's fixed assets consist of the building, vehicles, furniture, and IT equipment (e.g. computers, printers, servers). The ISO 14069 standard [44] also provides the possibility of calculating GHG emissions for capital goods using the same approach, while GHG protocol [26] does not include the amortisation period, but considers only emissions related to capital goods acquired/built during the year of the $C F$ calculation. 


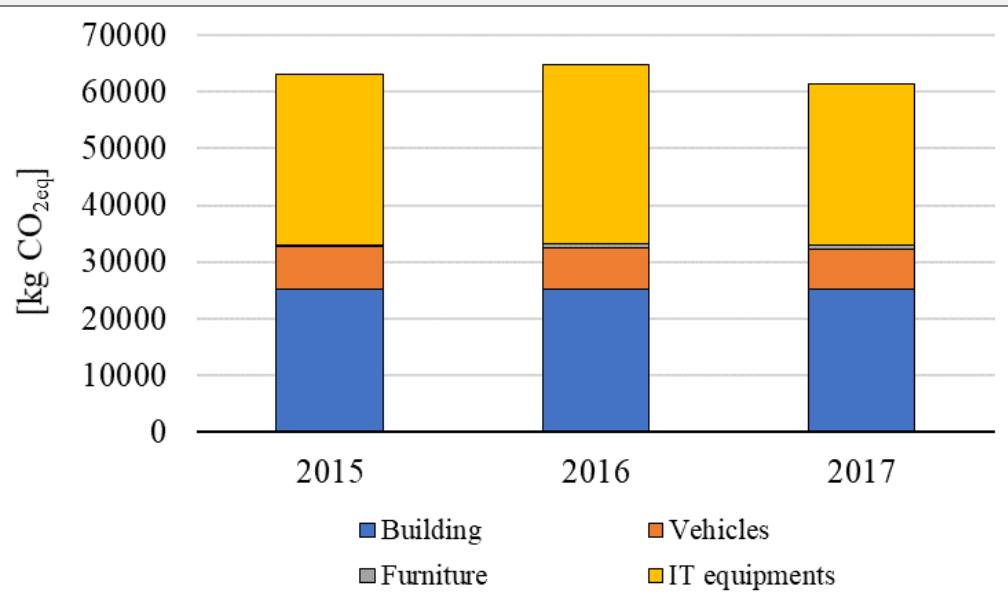

Figure 7. GHG emissions from capital goods

The $C F$ of EIHP for the period from 2015 to 2017, classified into the 23 categories defined by ISO 14069 norm, are presented in Table 4. The most significant contribution to the EIHP's $C F$ in 2017 was connected to the business travels $(32.7 \%)$, followed by indirect emissions from electricity consumption (12.4\%), transportation of clients and visitors (11.1\%), employee commuting (10.3\%), capital goods $(9.4 \%)$, indirect emissions from district heating $(8.0 \%)$, purchased goods $(6.9 \%)$ and direct emissions from mobile combustion (4.5\%). Other emission sources contributed less than $5 \%$ to the total EIHP's $C F$.

Table 4. The EIHP's $C F$ by emission categories for 2015, 2016 and 2017

\begin{tabular}{cccc}
\hline Emission categories & 2015 & 2016 & 2017 \\
\cline { 2 - 4 } 1. Direct emissions from stationary combustion sources & {$\left[\mathrm{t} \mathrm{CO}_{2 \mathrm{eq}}\right]$} & {$\left[\mathrm{t} \mathrm{CO} \mathrm{Ce}_{2}\right]$} & {$\left[\mathrm{t} \mathrm{CO}_{2 \mathrm{eq}}\right]$} \\
2. Direct emissions from mobile combustion sources & 19.8 & 28.2 & 29.0 \\
3. Direct emissions from processes & 0.0 & 0.0 & 0.0 \\
4. Direct fugitive emissions & 7.2 & 7.2 & 7.2 \\
5. Direct emissions from Land Use, Land-Use Change and Forestry (LULUCF) & 0.0 & 0.0 & 0.0 \\
Scope 1 emission categories (1-5) & 27.0 & 35.4 & 36.4 \\
6. Indirect emissions from electricity consumption & 88.4 & 82.3 & 80.6 \\
7. Indirect emissions from network energy consumption (excluding electricity) & 51.5 & 58.5 & 51.9 \\
Scope 2 emission categories (6-7) & 139.8 & 140.8 & 132.5 \\
8. Emissions due to energy not covered by sources from 1 to 7 & 17.2 & 18.9 & 18.3 \\
9. Purchased goods & 46.8 & 48.8 & 45.1 \\
10. Capital goods & 63.0 & 64.8 & 61.3 \\
11. Waste generated & 1.2 & 1.2 & 1.1 \\
13. Business travels & 3.2 & 3.7 & 3.7 \\
14. Upstream leased assets & 157.4 & 173.1 & 213.1 \\
15. Investments & 0.0 & 0.0 & 0.0 \\
12. Upstream transport and distribution & 0.0 & 0.0 & 0.0 \\
16. Transportation of clients and visitors & 73.3 & 74.2 & 72.0 \\
18. Use of sold products & 0.0 & 0.0 & 0.0 \\
19. End-of-life of sold products & 0.0 & 0.0 & 0.0 \\
20. Downstream franchises & 0.1 & 0.1 & 0.1 \\
21. Downstream leased assets & 0.0 & 0.0 & 0.0 \\
22. Employee commuting & 0.0 & 0.0 & 0.0 \\
23. Other indirect emissions & 59.7 & 65.0 & 67.3 \\
Scope 3 emission categories (8-23) & 0.0 & 0.0 & 0.0 \\
EIHP's CF & 421.9 & 449.6 & 481.9 \\
\hline 17. Downstream transportation of goods and distribution & 588.7 & 625.9 & 650.6 \\
\hline
\end{tabular}

Scope 1 activities contributed to the total GHG emissions with only 4.6-5.6\%, Scope 2 with 20.4-23.7\%, while Scope 3 with more than 70\%. Figure 8 shows the $C F$ of EIHP divided by scopes, in accordance with ISO 14064 and 14069 norms. 


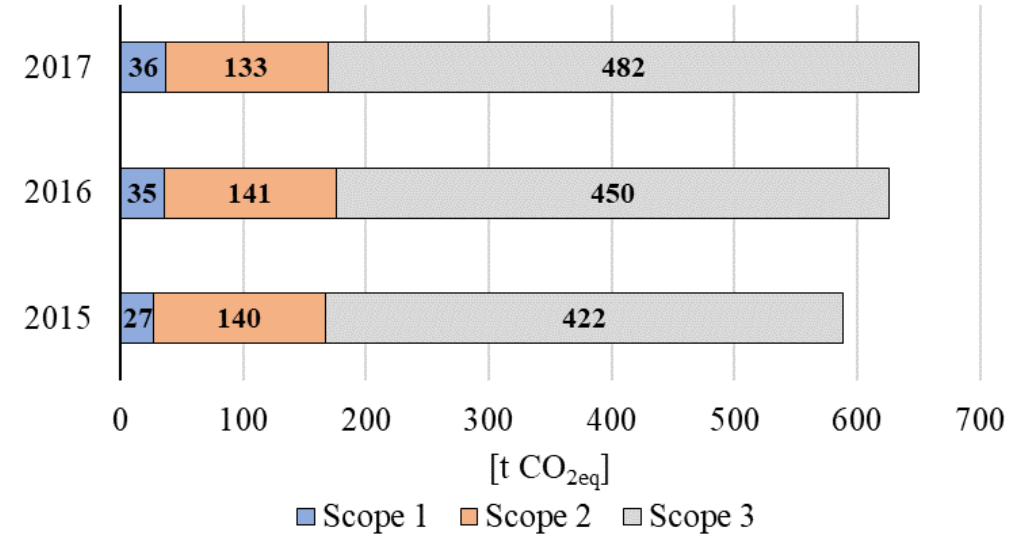

Figure 8. The EIHP's $C F$ by scopes for 2015, 2016 and 2017

The overall uncertainty of the $C F$ of EIHP for 2017 amounts to $6.7 \%$, while trend uncertainty (2015-2017) is estimated at 4.6\%, using Tier 1 method described in the IPCC Good Practice Guidance and Uncertainty Management in National Greenhouse Gas Inventories [46]. It means that the real EIHP's $C F$ for 2017 was between $607.1 \mathrm{t} \mathrm{CO}_{2 \mathrm{eq}}$ and $694.2 \mathrm{t} \mathrm{CO}_{2 \mathrm{eq}}$ in 2017 , while the estimated $C F$ by the Bilan Carbone ${ }^{\circledR}$ model was $650.6 \mathrm{t} \mathrm{CO}_{2 \text { eq. }}$.

\section{Comparison of carbon footprints}

The comparison of EIHP's $C F$ per employee with available data for selected EU institutions is shown in Figure 9 [36]. As it can be seen in figure, the $C F$ 's for EIHP were the lowest (7.45 t CO $\mathrm{CO}_{2 \mathrm{eq}}$ /employee in 2015, $7.28 \mathrm{t} \mathrm{CO}_{2 \mathrm{eq}} / \mathrm{employee}$ in 2016 and $7.31 \mathrm{t} \mathrm{CO}_{2 \mathrm{eq}}$ /employee in 2017). Although the absolute $C F$ of EIHP for 2017 was larger than its footprint for the previous years, due to the increase in number of employees, EIHP's $C F$ per employee in 2017 was slightly lower than $C F$ in 2015 and on the same level with $C F$ in 2016. It is essential to bear in mind that core businesses of compared institutions are significantly different. There are possible differences in the used calculation method, emission factors or set of collected activity data. Available $C F$ data for EU institutions refer to 2012 or 2014, while EIHP's $C F$ s were calculated for the period 2015-2017.

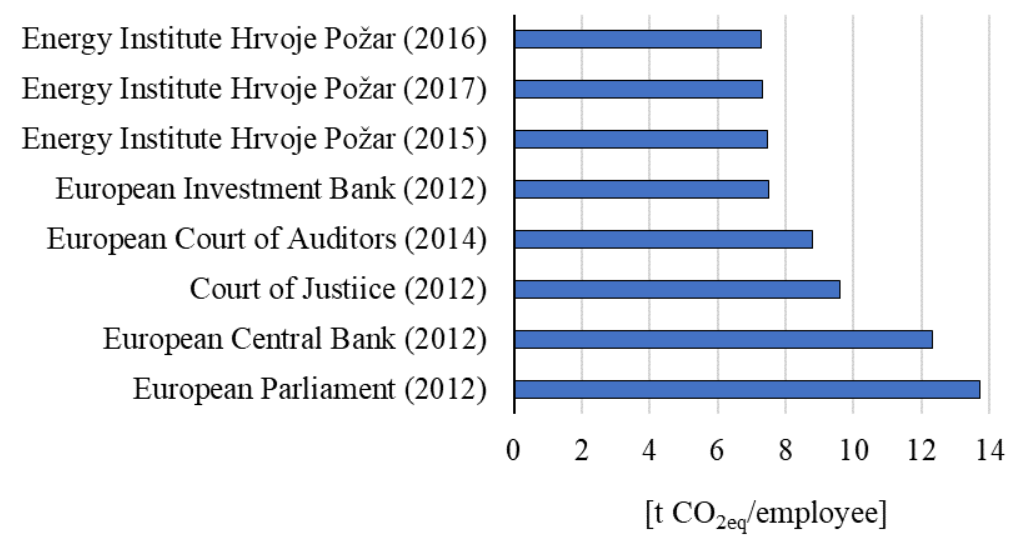

Figure 9. The comparison of organisations' $C F$ per employee

The precondition for a reliable comparison of the $C F$ of an organisation is the usage of the same calculation method in all compared organisations. Additionally, it is possible to compare only the similar types of organisation with approximately an equal number of employees. The usage of the comprehensive Bilan Carbone ${ }^{\circledR}$ model, on the EU level, 
fully in accordance with ISO standards (ISO 14064 and ISO/TR 14069) and GHG protocol, will ensure needed harmonisation in the calculation method. On the other hand, the difference in the number of employees within similar types of organisation could be solved by calculating the organisation's $C F$ per employee.

\section{CONCLUSIONS}

The Paris Agreement commits all countries to take measures to limit GHG emissions and strengthens the role of companies, civil society, financial institutions, cities, and regions. As a part of the solution to reduce GHG emissions, it is recommended to use a harmonised approach when calculating and reducing the $C F$ of public and private organisations. Therefore, the application of the comprehensive Bilan Carbone ${ }^{\circledR}$ model adapted to national conditions, fully in accordance with appropriate ISO standards and GHG protocol, is the proposed option. It would lead to comparable and reliable results at EU and even global level.

As an example, the EIHP's $C F$ has been calculated for the period from 2015 to 2017, by applying country-specific version of the Bilan Carbone ${ }^{\circledR}$ model. The $C F$ for 2017 was $650.6 \mathrm{t} \mathrm{CO}_{2 \mathrm{eq}}$, or $10.5 \%$ more than the result for the year 2015 . However, the $C F$ per employee in 2017 was $1.9 \%$ lower, due to an increase in the number of employees.

The calculation of the $C F$ is the first step in GHG emission reduction process, which will allow organisations to become familiar with the emission structure. It could be a decisive factor for organisations to identify and implement a well-balanced set of cost-effective measures. Implementation of measures would significantly contribute to the GHG emissions reduction and considerably facilitate the fulfilment of the Paris Agreement.

\section{ACKNOWLEDGMENT}

This research was part of the Clim'Foot project "Climate Governance: Implementing public policies to calculate and reduce organisations carbon footprint", co-funded through the LIFE Programme. This help is gratefully appreciated.

\section{NOMENCLATURE}

\section{Abbreviations}

$\begin{array}{ll}\text { ABC } & \text { Association Bilan Carbone } \\ \text { ADEME } & \text { French Agency for Environment and Energy Management } \\ C F & \text { Carbon Footprint } \\ \mathrm{CH}_{4} & \text { Methane } \\ \mathrm{CO}_{2} & \text { Carbon dioxide } \\ \mathrm{CO}_{2 \text { eq }} & \text { Carbon dioxide equivalent } \\ \mathrm{COP} & \text { Conference of the Parties } \\ \text { EIHP } & \text { Energy Institute Hrvoje Požar } \\ \text { ETS } & \text { Emissions Trading Scheme } \\ \text { EU } & \text { European Union } \\ \text { GHG } & \text { Greenhouse Gas } \\ \text { GWP } & \text { Global Warming Potential } \\ \text { HFC's } & \text { Hydrofluorocarbons } \\ \text { INDC } & \text { Intended Nationally Determined Contribution } \\ \text { IPCC } & \text { Intergovernmental Panel on Climate Change } \\ \text { ISO } & \text { International Organization for Standardization } \\ \text { LCA } & \text { Life Cycle Assessment } \\ \text { LIFE } & \text { Financial Instrument of the European Union } \\ \mathrm{N}_{2} \mathrm{O} & \text { Nitrous oxide }\end{array}$


$\mathrm{NF}_{3} \quad$ Nitrogen trifluoride

PFC's Perfluorocarbons

R417a Refrigerant

$\mathrm{SF}_{6} \quad$ Sulphur hexafluoride

UNFCCC United Nations Framework Convention on Climate Change

WMO World Meteorological Organization

\section{REFERENCES}

1. Baabou, W., Grunewald, N., Ouellet-Plamondon, C., Gressot, M. and Galli, A., The Ecological Footprint of Mediterranean Cities: Awareness Creation and Policy Implications, Environmental Science \& Policy, Vol. 69, pp 94-104, 2017, https://doi.org/10.1016/j.envsci.2016.12.013

2. Azapagic, A. and Perdan, S., Sustainable Development in Practice - Case Studies for Engineers and Scientists, Wiley-Blackwell, Chichester, West Sussex, UK, 2011.

3. Stocker, T. F., Qin, D., Plattner, G. K., Tignor, M. M. B., Allen, S. K., Boschung, J., Nauels, A., Xia, Y., Bex, V. and Midgley, P. M., Climate Change 2013 - The Physical Science Basis, Working Group I Contribution to the Fifth Assessment Report of the Intergovernmental Panel on Climate Change, IPCC, WMO, UNEP, Report, Cambridge University Press, Cambridge, UK, 2013.

4. Franchetti, M. J. and Apul, D., Carbon Footprint Analysis - Concepts, Methods, Implementation and Case Studies, CRC Press, Boca Raton, Florida, USA, 2013.

5. World Meteorological Organization, WMO Statement on the Status of the Global Climate in 2016, Communication and Public Affairs Office, 2017, https://library. wmo.int/doc_num.php?explnum_id=3414, [Accessed: 01-November-2018]

6. Zubelzu, S. and Álvarez Fernández, R., Carbon Footprint and Urban Planning, Incorporating Methodologies to Assess the Influence of the Urban Master Plan on the Carbon Footprint of the City, Springer Briefs in Applied Sciences, 2016, http://www.springer.com/series/8884, [Accessed: 01-November-2018]

7. United Nations, Paris Agreement, 2015 , http://unfccc.int/paris_agreement/items/9485.php, [Accessed: 01-November-2018]

8. European Commission, Submission by Latvia and the European Commission on Behalf of the European Union and its Member, Intended Nationally Determined Contribution of the EU and its Member States, 2015, http://wedocs.unep.org/handle/20.500.11822/18933, [Accessed: 01-November-2018]

9. European Commission, The EU Emissions Trading System (EU ETS), Climate Action, 2013, https://ec.europa.eu/clima/sites/clima/files/factsheet_ets_en.pdf, [Accessed: 01-November-2018]

10. Foo, D. C. Y. and Tan, R. R., A Review on Process Integration Techniques for Carbon Emissions and Environmental Footprint Problems, Process Safety and Environmental Protection, Vol. 103, Part B, pp 291-307, 2016, https://doi.org/10.1016/j.psep.2015.11.007

11. Pandey, D., Agrawal, M. and Pandey, J. S., Carbon Footprint: Current Methods of Estimation, Environmental Monitoring and Assessment, Vol. 178, No. 1-4, pp 135-160, 2011, https://doi.org/10.1007/s10661-010-1678-y

12. Strijov, V., Granić, G., Jurić, Ž., Jelavić, B. and Maričić, S. A., Integral Indicator of Ecological Impact of the Croatian Thermal Power Plants, Energy, Vol. 36, No. 7, pp 4144-4149, 2011, https://doi.org/10.1016/j.energy.2011.04.030

13.Edenhofer, O., Pichs-Madruga, R., Sokona, Y., Farahani, E., Kadner, S., Seyboth, K., Adler, A., Baum, I., Brunner, S., Eickemeier, P., Kriemann, B., Savolainen, J., Schlömer, S., von Stechow, C. and Zwickel, T., Climate Change 2014 - Mitigation of Climate Change, Contribution of Working Group III to the Fifth Assessment Report of 
the Intergovernmental Panel on Climate Change (IPCC), Cambridge University Press, Cambridge, UK, 2014.

14. Bhoyar, S. P., Dusad, S., Shrivastava, R., Mishra, S., Gupta, N. and Rao, A. B., Understanding the Impact of Lifestyle on Individual Carbon Footprint, Procedia Social and Behavioral Sciences, Vol. 133, pp 47-60, 2014, https://doi.10.1016/j.sbspro.2014.04.168

15. Fitzpatrick, J. J., McCarthy, S. and Byrne, E. P., Sustainability Insights and Reflections from a Personal Carbon Footprint Study: The Need for Quantitative and Qualitative Change, Sustainable Production and Consumption, Vol. 1, pp 34-46, 2015, https://doi.org/10.1016/j.spc.2015.05.00418

16. Robinson, A. J., Tewkesbury, A., Kemp, S. and Williams, I. D., Towards a Universal Carbon Footprint Standard: A Case Study of Carbon Management at Universities, Journal of Cleaner Production, Vol. 172, pp 4435-4455, 2018, https://doi.org/10.1016/j.jclepro.2017.02.147

17. Welsch, M., Pye, S., Keles, D., Faure-Schuyer, A., Dobbins, A., Shivakumar, A., Deane, P. and Howells, M., Europe's Energy Transition - Insights for Policy Making, Academic Press, an imprint of Elsevier, London, UK, 2017.

18. Chakraborty, D. and Roy, J., Energy and Carbon Footprint: Numbers Matter in Low Energy and Low Carbon Choices, Current Opinion in Environmental Sustainability, Vol. 5, No. 2, pp 237-243, 2013, https://doi.10.1016/j.cosust.2013.04.001

19. Hertwich, E. and Peters, G., Carbon Footprint of Nations: A Global, Trade-Linked Analysis, Environmental Science \& Technology, Vol. 43, No. 16, pp 6414-6420, 2009, https://doi.10.1021/es803496a

20. Kanemoto, K., Moran, D. and Hertwich, E. G., Mapping the Carbon Footprint of Nations, Environmental Science \& Technology, Vol. 50, No. 19, pp 10512-10517, 2016, https://doi.10.1021/acs.est.6b03227

21. Muthu, S. S. and Golinska, P., Assessment of Carbon Footprint in Different Industrial Sectors, Vol. 1-2, EcoProduction, Environmental Issues in Logistics and Manufacturing, Springer, Berlin, Germany, 2014.

22. Muthu, S. S. and Abanda, F. H., The Carbon Footprint Handbook, CRC Press, Boca Raton, Florida, USA, 2016.

23.Lombardi, M., Laiola, E., Tricase, C. and Rana, R., Assessing the Urban Carbon Footprint: An Overview, Environmental Impact Assessment Review, Vol. 66, pp 43-52, 2017, https://doi.10.1016/j.eiar.2017.06.005

24. Gao, T., Liu, Q. and Wang, J., Comparative Study of Carbon Footprint and Assessment Standards, Journal of Low-Carbon Technologies, Vol. 9, No. 3, pp 237-243, 2014, https://doi.org/10.1093/ijlct/ctt041

25. International Standard Organization, ISO 14064-1: Greenhouse Gases - Part 1: Specification with Guidance at the Organization Level for Quantification and Reporting of GHG Emissions and Removals, 2006.

26. Ranganathan, J., Corbier, L., Bhatia, P., Schmitz, S., Gage, P. and Oren, K., GHG Protocol, Corporate Accounting and Reporting Standard (revised ed.), World Business Council for Sustainable Development \& World Resources Institute, 2004.

27. Klein-Banai, C. and Theis, T. L., Quantitative Analysis of Factors Affecting Greenhouse Gas Emissions at Institutions of Higher Education, Journal of Cleaner Production, Vol. 48, pp 29-38, 2013, https://doi.org/10.1016/j.jclepro.2011.06.004

28. Dias, A. C. and Arroja, L., Comparison of Methodologies for Estimating the Carbon Footprint - Case Study of Office Paper, Journal of Cleaner Production, Vol. 24, pp 30-35, 2012, https://doi.10.1016/j.jclepro.2011.11.005

29. Smolek, P., Leobner, I., Heinzl, B., Gourlis, G. and Ponweiser, K., A Method for Real-Time Aggregation of a Product Footprint during Manufacturing, Journal of Sustainable Development of Energy, Water and Environment Systems, Vol. 4, No. 4, pp 360-378, 2016, https://doi.org/10.13044/j.sdewes.2016.04.0028 
30. Barnett, A., Barraclough, R. W., Becerra, V. and Nasuto, S., A Comparison of Methods for Calculating the Carbon Footprint of a Product, p 8, University of Reading, Reading, UK, 2012.

31. Minx, J. C., Wiedmann, T., Wood, R., Peters, G. P., Lenzen, M., Owen. A., Scott, K., Barrett, J., Hubacek, K., Baiocchi, G., Paul, A., Dawkins, E., Briggs, J., Guan, D., Suh, S. and Ackerman, F., Input-Output Analysis and Carbon Footprinting: An Overview of Applications, Economic Systems Research, Vol. 21, No. 3, pp 187-216, 2009, https://doi.org/10.1080/09535310903541298

32. Aroonsrimorakot, S., Yuwaree, C., Arunlertaree, C., Hutajareorn, R. and Buadit, T., Carbon Footprint of Faculty of Environment and Resource Studies, Mahidol University, Salaya Campus, Thailand, APCBEE Procedia, Vol. 5, pp 175-180, 2013, https://doi.org/10.1016/j.apcbee.2013.05.031

33. Utaraskul, T., Carbon Footprint of Environmental Science Students in Suan Sunandha Rajabhat University, Thailand, Procedia - Social and Behavioral Sciences, Vol. 197, pp 1156-1160, 2015, https://doi.org/10.1016/j.sbspro.2015.07.371

34. Abdul-Azeez, I. A. and Ho, C. S., Realizing Low Carbon Emission in the University Campus Towards Energy Sustainability, Open Journal of Energy Efficiency, Vol. 4, No. 2, pp 15-27, 2015, https://doi.org/10.4236/ojee.2015.42002

35. Komarek, T. M., Lupi, F., Kaplowitz, M. D. and Thorp, L., Influence of Energy Alternatives and Carbon Emissions on an Institution's Green Reputation, Journal of Environmental Management, Vol. 128, pp 335-344, 2013, https://doi.org/10.1016/j.jenvman.2013.05.002

36. Factor-X, European Court of Auditors, Carbon Footprint Report 2014, The Climate Consulting Group SPRL, Belgium, 2016, https://www.eca.europa.eu/bg/Documents/ ECA_Carbon_footprint_report_2014_EN.pdf, [Accessed: 01-November-2018]

37. Sotos, M., Bhatia, P., Cummis, C., Didden, M., Kovac, M., Ryor, J. and Stevens, A., GHG Protocol, Scope 2 Guidance, An Amendment to the GHG Protocol, World Resources Institute, Washington, D. C., USA, 2015.

38. Bhatia, P., Cummis, C., Brown, A., Rich, D., Draucker, L. and Lahd, H., GHG Protocol, Corporate Value Chain (Scope 3) Standard, Supplement to the GHG Protocol Corporate Accounting and Reporting Standard, World Business Council for Sustainable Development \& World Resources Institute, 2011.

39. Barrow, M., Buckley, B., Caldicott, T., Cumberlege, T., Hsu, J. and Kaufman, S., GHG Protocol, Technical Guidance for Calculating Scope 3 Emissions, Supplement to the Corporate Value Chain (Scope 3) Accounting \& Reporting Standard, Corporate Value Chain, World Business Council for Sustainable Development \& World Resources Institute in Partnership with the Carbon Trust, 2013.

40. International Standard Organization, ISO 14040: Environmental Management - Life Cycle Assessment - Principles and Framework, European Standard, 2006.

41. International Standard Organization, ISO 14044: Environmental Management - Life Cycle Assessment - Requirements and Guidelines, European Standard, 2006.

42. International Standard Organization, ISO 14064-2: Greenhouse Gases - Part 2: Specification with Guidance at the Project Level for Quantification, Monitoring and Reporting of GHG Emission Reductions and Removal Enhancements, 2006.

43. International Standard Organization, ISO 14064-3: Greenhouse Gases - Part 3: Specification with Guidance for the Validation and Verification of GHG Assertions, 2006.

44. International Standard Organization, ISO/TR 14069: Greenhouse Gases Quantification and Reporting of GHG Emissions for Organizations - Guidance for the Application of ISO 14064-1, 2013.

45. Eggleston, S., Buendia, L., Miwa, K., Ngara, T., Tanab, K., et al., 2006 IPCC Guidelines for National Greenhouse Gas Inventories, Volume 1 - General Guidance and Reporting, 
Volume 2 - Energy, Volume 3 - Industrial Processes and Product Use, Volume 4 Agriculture, Forestry and Other Land Use, Volume 5 - Waste, WMO, IPCC, UNEP, Task Force on National Greenhouse Gas Inventories, 2006, https://www.ipcc-nggip.iges.or.jp/public/2006gl/, [Accessed: 01-November-2018]

46. Penman, J., Kruger, D. and Galbally, I., IPCC Good Practice Guidance and Uncertainty Management in National Greenhouse Gas Inventories, IPCC, 2001, https://www.ipcc-nggip.iges.or.jp/public/gp/english/, [Accessed: 01-November-2018] 